\title{
Culinary quality and sensory profile of cassava varieties harvested at different ages
}

\section{Qualidade culinária e perfil sensorial de variedades de mandioca de mesa colhidas em diferentes idades}

\author{
Ronielli Cardoso Reis ${ }^{1 *}$; Luciana Alves de Oliveira ${ }^{1}$; Jamille Mota Almeida2; \\ Palmira de Jesus Neta ${ }^{3}$; Fabrine Dias Santos ${ }^{4}$; Vanderlei da Silva Santos ${ }^{1}$; \\ Renato Souza Cruz $^{5}$
}

\section{Highlights}

Cooking time was influenced by the soluble solid, sugar and cyanogen contents. Harvest age has a significant effect on the culinary quality of boiled cassava

The creamy, soft and sticky terms were associated with acceptance of the roots.

The floury, hard and fibrous terms were associated with the rejection of the roots.

It was possible to define the best harvest age of the evaluated varieties.

\begin{abstract}
Sweet cassava must be rapidly cooked and meet the sensory and technological requirements of consumers. The objectives of this study were to evaluate the culinary quality of sweet cassava varieties harvested at three ages and obtain the sensory profile of these varieties using the check-all-that-apply method (CATA). Roots of three cassava varieties released or recommended by Embrapa (BRS Aipim Brasil, BRS Dourada and Saracura) and the commercial variety Eucalipto, harvested at nine, 12 and 15 months of age, were evaluated for physical, chemical and sensory aspects. At nine months of age, the Saracura, BRS Aipim Brasil and BRS Dourada varieties did not differ in cooking time, averaging $41.62 \mathrm{~min}$. The Eucalipto variety had similar cooking times at the three harvest ages, averaging $21.83 \mathrm{~min}$. There was a difference between the four varieties at nine months, with Saracura exhibiting the lowest acceptance score (5.0) and differing from the Eucalipto variety, which showed an average score of 6.3. At 12 months of age, there was a significant increase in the acceptance of the Saracura and BRS Aipim Brasil varieties, which did not differ from Eucalipto and had an average score of 6.4. Consumers perceived differences between the sensory

1 Researchers, Brazilian Agricultural Research Corporation, EMBRAPA Cassava and Fruit, Cruz das Almas, BA, Brazil. E-mail: ronielli.reis@embrapa.br; luciana.oliveira@embrapa.br; vanderlei.silva-santos@embrapa.br

2 Pharmaceutist, Maria Milza College, FAMAM, Governador Mangabeira, BA, Brasil. E-mail: jamille_jma@hotmail.com

3 Student of the Graduation Course in Forest Engineering, Federal University of Recôncavo of Bahia, UFRB, Cruz das Almas, BA, Brazil. E-mail: palmiraneta@hotmail.com

${ }^{4}$ Student of the Nutrition Graduation Course, Maria Milza College, FAMAM, Governador Mangabeira, BA, Brazil. E-mail: fabrinedias@hotmail.com.br

${ }^{5}$ Prof., State University of Feira de Santana, UEFS, Feira de Santana, BA, Brazil. E-mail: cruz.rs@uefs.br

* Author for correspondence
\end{abstract}

Received: July 24, 2020 - Approved: Nov. 09, 2020 
characteristics of the cassava varieties using CATA. The sensory terms "creamy", "soft" and "sticky" can be associated with greater acceptance of cooked cassava roots, whereas terms such as "floury", "slightly bitter", "no taste", "hard" and "fibrous" can be associated with less acceptance and are therefore undesirable from the consumer's point of view. Principal component analysis showed that the age at which the roots were harvested had a great effect on the culinary quality of cassava, regardless of the evaluated variety. The commercial variety Eucalipto was well-accepted by the consumers irrespective of root age and can be harvested at any of the evaluated ages. For the Saracura, BRS Aipim Brasil and BRS Dourada varieties, harvesting is recommended at 12 or 15 months so that better quality roots are obtained.

Key words: CATA. Chemical composition. Cooking. texture. Manihot esculenta. Sensory acceptance.

\section{Resumo}

A mandioca de mesa deve apresentar rápido cozimento e atender às exigências sensoriais e tecnológicas dos consumidores. O objetivo dessa pesquisa foi avaliar a qualidade culinária de variedades de mandiocas de mesa colhidas em três idades e obter o perfil sensorial dessas variedades utilizando o método checkall-that-apply (CATA). Foram avaliadas raízes de três variedades de mandioca de mesa lançadas ou recomendadas pela Embrapa (BRS Aipim Brasil, BRS Dourada e Saracura) e a variedade comercial Eucalipto, colhidas aos nove, 12 e 15 meses de idade, quanto aos aspectos físicos, químicos e sensoriais. Aos nove meses de idade, as variedades Saracura, BRS Aipim Brasil e BRS Dourada não diferiram entre si quanto ao tempo de cozimento, e tais raízes apresentaram o tempo médio de 41,62 min. A variedade Eucalipto apresentou tempo de cozimento similar nas três épocas de colheita, com valor médio de 21,83 minutos. Houve diferença entre as quatro variedades e aos nove meses a variedade Saracura apresentou a menor nota de aceitação $(5,0)$, diferindo da variedade Eucalipto, que apresentou nota média de 6,3. Aos 12 meses de idade houve um aumento significativo na aceitação das variedades Saracura e BRS Aipim Brasil, que não diferiram da variedade Eucalipto e apresentaram nota média de 6,4. Os consumidores perceberam diferenças entre as características sensoriais das variedades de mandioca utilizando o CATA. Os termos sensoriais "cremosa", "macia" e "pegajosa" podem ser associados à maior aceitação das raízes de mandioca cozida, enquanto que termos como "farinhenta", "levemente amargo", "sem sabor", "dura" e "fibrosa", podem ser associados à menor aceitação, sendo, portanto indesejáveis do ponto de vista do consumidor. Pela análise de componentes principais verificou-se que a idade de colheita das raízes exerce um grande efeito sobre a qualidade culinária da mandioca de mesa, independentemente da variedade avaliada. A variedade comercial Eucalipto foi bem aceita pelos consumidores, independente da idade da raiz e, portanto, pode ser colhida em qualquer uma das idades avaliadas. Para as variedades Saracura, BRS Aipim Brasil e BRS Dourada, indica-se que a colheita seja feita aos 12 ou 15 meses, a fim de obter raízes de melhor qualidade. Palavras-chave: CATA. Composição química. Cozimento. Textura. Manihot esculenta. Aceitação sensorial.

\section{Introduction}

Cassava (Manihot esculenta Crantz) is one of the most important crops worldwide, growning in several tropical countries in Africa,
Latin America and Asia. Brazil is the fifth-largest producer of cassava in the world, having generated 17.6 million tons of the product in 2018 (Food and Agriculture Organization of the United Nations [FAO], 2020). 
In Brazil, the largest producing regions are the north and northeast, which account for approximately $55 \%$ of the national production. In the northeast region, the states of Ceará and Bahia stand out, having produced 622 and 610 thousand tons of cassava in 2018, respectively (Instituto Brasileiro de Geografia e Estatística [IBGE], 2019).

Of the several commercial sweet varieties available for cultivation in Bahia, Eucalipto is the most planted in the region of Recôncavo Baiano and is highlighted for its short cooking time and lesser physiological deterioration. However, other cassava varieties with good agronomic traits, higher carotenoid content and good culinary quality have been released or recommended by Embrapa Cassava \& Fruits for the northeast region. In this context, the following varieties stand out: BRS Aipim Brasil, an early-developing variety recommended for the regions of Cruz das Almas and Conceição do Almeida - BA; BRS Dourada, an early-developing variety with high carotenoid content, released in different municipalities in Bahia (Araújo \& Almeida, 2013); and Saracura, a high-yielding variety recommended for the regions of Nossa Senhora das Dores and Lagarto - SE (Carvalho et al., 2007).

The culinary quality of cassava roots is usually assessed by physical and chemical analyses such as determination of cooking time and cyanogenic compounds, starch and fiber contents, and regarding sensory aspects, through the evaluation of the texture and taste of the cooked mass. These characteristics vary according to the variety, type of soil, plant age and even between roots of the same plant (Pedri et al., 2018).

The instability of culinary quality in cassava roots can lead to losses for producers and consumers due to uncertainties regarding the quality of their production and purchasing, respectively (Oliveira \& Moraes, 2009). In this scenario, several studies have been carried out to understand the variations in culinary characteristics of cassava roots according to planting time, genotype, pruning time, among others (Padonou, Mestres, \& Nago, 2005; Oliveira et al., 2010; Franck et al., 2011; Talma et al., 2013; Pedri et al., 2018).

Among the determining factors for the culinary quality of cassava roots, cooking time is considered one of the most important. In this respect, cooking times below 30 min are deemed acceptable, but times between 10 and 20 min are considered optimal for the quality of cooked roots (Beleia, Butarelo, \& Silva, 2006). Besides, the mass must be friable; that is, it must be brittle and easily crushed after cooking (Kouadio, Nindjin, Bonfoh, N'Dri, \& Amani, 2011).

Although friability is considered one of the most important attributes for boiled cassava quality, this characteristic may be desirable or not depending on the purpose for which the roots are used (Talma et al., 2013). In the case of boiled cassava, sensoryacceptance tests should be carried out to complement the information on the characteristics of the roots that influence acceptance by consumers.

Regarding the sensory attributes, texture has usually been evaluated concerning its friability, whereas taste has been analyzed in terms of sweetness or bitterness of the roots (Franck et al., 2011; Padonou et al., 2005; Sanoussi et al., 2015; Pedri et al., 2018). On this topic, Padonou et al. (2005) and Franck et al. (2011) correlated the chemical and instrumental characteristics of boiled cassava roots with the sensory attributes of color, taste and friability, which were obtained by trained panels. However, tests with consumers were 
not carried out, so no information on how these attributes can interfere with the acceptance of cassava is available.

Traditional sensory tests are based on consumer tests focus on hedonic responses, and descriptive analyses that are performed by a trained panel using intensity scales. Nonetheless, creating a panel of trained assessors is laborious, time-consuming and costly, so simpler methods have been employed whereby consumers describe the products (Beldarrain et al., 2020). Among these methods, the check-all-that-apply (CATA) questionnaire stands out, as it allows for an assessment of consumers' perception of a product based on the choice of terms from a pre-defined list (Jaeger et al., 2020). By combining hedonic responses with CATA, it is possible to elucidate the sensory factors related to the acceptability of a given product (Ares et al., 2010).

The CATA method has been used to describe different food matrices such as desserts (Ares et al., 2010), strawberries (Lado, Vicente, Manzzioni, \& Ares, 2010) meats (Beldarrain et al., 2020), bread (Boukid et al., 2020; Aguiar, Rodrigues, Queiroz, Melo, \& Pineli, 2020) and cheeses (Oliveira et al., 2017). However, no studies have been found in the literature that employed this methodology to obtain the sensory profile of cassava varieties. The use of this methodology, in association with acceptance tests, is of great relevance, as it makes it possible to identify the sensory characteristics that increase the acceptance of a cooked cassava variety by the consumer.

Hence, this study was conducted to evaluate the culinary quality of four varieties of cassava harvested at three ages and obtain the sensory profile of these varieties using the CATA method.

\section{Materials and Methods}

The varieties were grown in the experimental field of Embrapa Cassava \& Fruits, in Cruz das Almas, Bahia, Brazil (12 ${ }^{\circ} 67^{\prime}$ $\mathrm{S}$ and $39^{\circ} 15^{\prime} \mathrm{W}, 199 \mathrm{~m}$ asl), from June 2016 to August 2017. According to the Köppen classification, the region's climate is an Aw to Am type (hot and humid tropical). During the study period, the average annual temperature was $23.7{ }^{\circ} \mathrm{C}$, the average relative humidity was $82.1 \%$ and precipitation was $1,305.2 \mathrm{~mm}$ (Agritempo, 2020). The soil in the experimental area is classified as a Dystrophic-Cohesive Argisolic Yellow Latosol (Santos et al., 2018).

Three cassava varieties released or recommended by Embrapa Cassava \& Fruits (BRS Aipim Brasil, BRS Dourada and Saracura) and the Eucalipto variety, which is the most planted and consumed in the region of Recôncavo Baiano, were harvested at nine, 12 and 15 months old. The experiment was laid out in a randomized-block design with three blocks and 25 plants per plot, in a 4 (varieties) $\times 3$ (root ages) factorial arrangement.

Sampling was performed according to the methodology described by RodriguezAmaya and Kimura (2004). Root length was determined from one end to the other using a tape measure, and diameter was measured in the middle portion of the root with a digital caliper. The soluble solids content was determined by direct reading on a digital refractometer after filtering the sample through voile fabric. Cyanogenic compounds were determined as proposed by Essers (1994), and the enzyme linamarase was extracted from the cassava inner bark following Cooke (1979).

The ground mass was dried in a forcedair oven at $70^{\circ} \mathrm{C}$ until reaching constant weight 
to determine dry matter. The dry sample was used in chemical analysis. Starch was analyzed following the methodology described by Holm and Bjorck (1986). The sugar content was measured by spectrophotometry, by the methodology of Somogyi (1945) and Nelson (1944), with the acid hydrolysis stage for determining total sugars, according to Zenebon, Pascuet and Tiglea (2008). Lipids, dietary fiber and ash contents were quantified according to the methodology proposed by Zenebon et al. (2008). The protein content was determined by the Kjeldahl method, following the protocol described by the Ministry of Agriculture (Ministério da Agricultura Pecuária e Abastecimento [MAPA], 2006).

The Mattson cooker method modified and adapted by Feniman (2004) was used to measure the cooking time. Eight roots of each variety were peeled and cut into $6-\mathrm{cm}$ long cylinders. Twelve cylinders from each root were randomly selected and placed perpendicular to the cut in the Mattson cooker. The cooker was then immersed in boiling water at the ratio of $100 \mathrm{~g}$ of roots to $1 \mathrm{~L}$ of distilled water. A needle with a 90-g stainless-steel peg was placed on top of each cylinder, and the average cooking time was considered when the tenth peg descended $2 \mathrm{~cm}$.

Cutting resistance was determined by following the methodology described by Talma et al. (2013), using five replicates for the raw and cooked roots of each variety. Pieces $3-\mathrm{cm}$ long, from the middle portion of the root were cut in half lengthwise and evaluated on the TA.TX Plus Texture Analyzer (Stable Micro Systems, England), which operated with force measurement in compression and a WarnerBratzler Blade HDP/BSW probe, at the pre-test speed of $0.2 \mathrm{~cm} \mathrm{~s}^{-1}$, post-test and test speed of $0.5 \mathrm{~cm} \mathrm{~s}^{-1}$, and distance of $5 \mathrm{~cm}$.
For the sensory tests to be conducted, the study was approved by the Research Ethics Committee and registered under CAAE no. 23109213.9.0000.5556. The tests (acceptance and CATA) were carried out in individual booths, under white light. Each consumer received a piece of cooked cassava, approximately $30 \mathrm{~g}$, monadically and sequentially, in a complete block design, in a total of four samples. The tests were performed by 60 cassava consumers, who assessed the overall acceptance of the cooked roots using the nine-point hedonic scale.

Three focus group sessions were held to define the terms of the CATA questionnaire. They were conducted in a round table, with a group of eight to ten consumers in each session. During the sessions, the four cassava varieties that would be evaluated in the sensory acceptance test were presented. The consumers tasted each sample and wrote down all the sensory attributes, referring to the color, aroma, taste and texture perceived during the tasting. The sensory terms that appeared most frequently in the three sessions were selected to compose the evaluation form. A total of sixteen terms were selected, four of which were associated with the color of the roots ("cream", "yellow", "shiny" and "white"), two with their aroma ("cassava" and "green corn"), four with the taste ("cassava-like", "no taste/watery", "sweet" and "slightly bitter") and six with the texture ("soft", "hard", "sticky", "fibrous", "creamy" and "floury"). The CATA was answered along with the acceptance test, and the terms were presented to each consumer in a random order.

All data were subjected to analysis of variance, and in case of a significant $F(p \leq 0.05)$, Tukey's test was performed at $5 \%$ significance. Physical, physico-chemical and chemical 
data were subjected to principal component analysis (PCA) from the correlation matrix, which generated a graphical representation of the evaluated varieties and characteristics. Pearson's linear correlation analysis (R) was also performed between each of the physical, physico-chemical and chemical characteristics and sensory acceptance. The citation frequencies for each CATA term were subjected to Cochran's $Q$ test at $5 \%$ probability and, when significant, the McNemar test was performed at $5 \%$ significance. The CATA data were also arranged in a matrix with the varieties in the rows and the attributes/terms in the columns and subjected to correspondence analysis to obtain a two-dimensional representation of the relationship between the samples and the attributes. All statistical analyses were carried out using the Statistica 7.0 (STATSOFT, 2008) and R (R Core Team [R], 2018) programs.

\section{Results and Discussion}

High coefficients of variation above $30 \%$ between the root varieties (CV1) and ages (CV2) were observed for the following characteristics: cutting resistance of cooked roots, cooking time (Table 1), cyanogenic compounds, total sugars and protein (Table 2). These CV values indicate the existence of great variability between the roots, for these characteristics.

Significant interactions between the root age and variety factors were observed for cooking time, soluble solids (Table 1), dry matter, starch, total sugars, protein and ash (Table $2)$, which indicates that these characteristics varied with root age and differently for each variety. A similar result for cooking time was reported by Pedri et al. (2018), who evaluated different varieties of cassava.

There was no difference between the varieties for root dimensions. At 15 months, the roots exhibited the highest length (24.30 $\mathrm{cm}$ ) and diameter $(4.73 \mathrm{~cm})$ values (Table 1). The same was observed for cutting resistance, which increased at 15 months of age in both raw and cooked roots. Raw roots of the Eucalipto variety showed higher cutting resistance than the Saracura and BRS Aipim Brasil varieties; however, after cooking, there was no difference between the four varieties. The increased cutting resistance of the roots (raw or cooked) did not influence cooking time, and there was no significant correlation between these variables (Table 3). A different result was reported by Talma et al. (2013), who observed a significant moderate correlation $(R=0.62)$ between the cutting resistance of the cooked flesh and cooking time. 
Table 1

Physical and physico-chemical characteristics of the cassava varieties

\begin{tabular}{|c|c|c|c|c|c|c|c|}
\hline Variable & Age & Eucalipto & Saracura & $\begin{array}{l}\text { BRS Aipim } \\
\text { Brasil }\end{array}$ & $\begin{array}{c}\text { BRS } \\
\text { Dourada }\end{array}$ & Mean & CV1 \\
\hline \multirow{5}{*}{$\begin{array}{l}\text { Length }{ }^{(1)} \\
\text { (cm) }\end{array}$} & 9 & 20.42 & 20.06 & 19.92 & 19.16 & $19.89^{\mathrm{B}}$ & 14.93 \\
\hline & 12 & 23.45 & 22.18 & 23.74 & 23.01 & $23.09^{A}$ & 6.24 \\
\hline & 15 & 23.94 & 24.99 & 24.46 & 23.82 & $24.30^{A}$ & 7.31 \\
\hline & Mean & $22.60^{\text {ns }}$ & $22.41^{\text {ns }}$ & $22.71^{\text {ns }}$ & $22.00^{\text {ns }}$ & & \\
\hline & CV2 & 14.68 & 12.89 & 13.03 & 11.58 & & \\
\hline \multirow{5}{*}{$\begin{array}{l}\text { Diameter(1) } \\
\text { (cm) }\end{array}$} & 9 & 3.74 & 3.67 & 3.62 & 4.00 & $3.76^{c}$ & 6.56 \\
\hline & 12 & 4.45 & 3.92 & 4.36 & 4.46 & $4.30^{B}$ & 10.44 \\
\hline & 15 & 4.84 & 4.70 & 4.43 & 4.92 & $4.73^{\mathrm{A}}$ & 9.30 \\
\hline & Mean & $4.35^{\mathrm{ns}}$ & $4.10^{\text {ns }}$ & $4.13^{\text {ns }}$ & $4.46^{\mathrm{ns}}$ & & \\
\hline & CV2 & 15.86 & 12.46 & 10.17 & 12.58 & & \\
\hline \multirow{5}{*}{$\begin{array}{l}\text { CRRaw }^{(1)} \\
\text { (gF) }\end{array}$} & 9 & 13098.94 & 11499.34 & 9902.47 & 11947.46 & $11612.05^{c}$ & 11.48 \\
\hline & 12 & 15247.93 & 11817.57 & 14151.09 & 15389.28 & $14151.47^{B}$ & 16.19 \\
\hline & 15 & 20131.99 & 14231.83 & 16008.33 & 16589.46 & $16740.41^{\mathrm{A}}$ & 17.78 \\
\hline & Mean & $16159.62^{\mathrm{a}}$ & $12516.25^{b}$ & $13353.96^{b}$ & $14642.07^{a b}$ & & \\
\hline & CV2 & 26.06 & 11.61 & 21.59 & 15.08 & & \\
\hline \multirow{5}{*}{$\begin{array}{c}\text { CRCooked }^{(1)} \\
(\mathrm{gF})\end{array}$} & 9 & 1687.28 & 1610.09 & 1471.67 & 1756.58 & $1631.40^{\mathrm{AB}}$ & 26.47 \\
\hline & 12 & 1163.89 & 1647.80 & 707.35 & 1308.44 & $1206.87^{B}$ & 44.84 \\
\hline & 15 & 1995.59 & 2022.25 & 1375.44 & 1622.28 & $1753.89^{A}$ & 24.16 \\
\hline & Mean & $1615.58^{\text {ns }}$ & $1760.04^{\text {ns }}$ & $1184.82^{\mathrm{ns}}$ & $1562.43^{\text {ns }}$ & & \\
\hline & CV2 & 29.10 & 19.13 & 43.60 & 37.80 & & \\
\hline \multirow{5}{*}{$\begin{array}{l}\text { Cooking time } \\
\text { (min) }\end{array}$} & 9 & $20.96 b^{A}$ & $41.83 \mathrm{a}^{\mathrm{A}}$ & $36.11 \mathrm{a}^{\mathrm{A}}$ & $46.58 a^{A}$ & 36.73 & 31.50 \\
\hline & 12 & $22.01 b^{A}$ & $20.79 b^{B}$ & $23.68 a b^{B}$ & $34.62 a^{B}$ & 25.28 & 29.59 \\
\hline & 15 & $22.52 \mathrm{a}^{\mathrm{A}}$ & $24.05 a^{B}$ & $18.12 \mathrm{a}^{\mathrm{B}}$ & $29.67 a^{B}$ & 23.59 & 22.33 \\
\hline & Mean & 21.83 & 28.89 & 25.97 & 34.21 & & \\
\hline & CV2 & 20.44 & 35.43 & 37.90 & 24.09 & & \\
\hline \multirow{5}{*}{$\begin{array}{l}\text { Soluble solids(2) } \\
\text { ('Brix) }\end{array}$} & 9 & $6.51 b^{A}$ & $7.70 \mathrm{a}^{\mathrm{A}}$ & $6.22^{\mathrm{bA}}$ & $8.11^{\mathrm{aA}}$ & 7.14 & 13.37 \\
\hline & 12 & $4.03^{\mathrm{aB}}$ & $4.45^{\mathrm{aB}}$ & $4.51^{\mathrm{aB}}$ & $4.54^{\mathrm{aB}}$ & 4.38 & 13.16 \\
\hline & 15 & $4.98^{\mathrm{aB}}$ & $5.18^{\mathrm{aB}}$ & $5.44 \mathrm{a}^{\mathrm{AB}}$ & $5.32^{\mathrm{aB}}$ & 5.23 & 4.58 \\
\hline & Mean & 5.17 & 5.78 & 5.39 & 5.99 & & \\
\hline & CV2 & 21.99 & 26.38 & 15.92 & 28.63 & & \\
\hline
\end{tabular}

CRRaw $=$ cutting resistance of raw roots; CRCooked $=$ cutting resistance of cooked roots. ${ }^{(1)}$ Non-significant interaction between the root variety and age factors. (2)Significant interaction between the root variety and age factors. ${ }^{\text {ns }}$ not significant by the $\mathrm{F}$ test at $5 \%$ probability. $\mathrm{CV} 1$ = coefficient of variation between varieties; $\mathrm{CV} 2$ = coefficient of variation between harvest ages. Means followed by common lowercase letters in the row and uppercase letters in the column do not differ at the $5 \%$ significance level by Tukey's test. 
At nine months of age, the Saracura, BRS Aipim Brasil and BRS Dourada varieties did not differ for cooking time, averaging 41.62 min, which is longer than the maximum time considered suitable for consumption (Table 1). The cooking time of these three varieties decreased significantly with root age, and, at 15 months, the times ranged from $18.12 \mathrm{~min}$ (BRS Aipim Brasil) to 29.67 min (BRS Dourada), which are considered adequate values. In contrast, Pedri et al. (2018) reported an increase in cooking time with root age for the
Cacau branca, Cacau roxa, Cacau amarela and Mandioca pão varieties. The Eucalipto variety showed similar cooking times in the three harvest seasons, averaging $21.83 \mathrm{~min}$, close to the 26 min observed by Talma et al. (2013) in this variety harvested at 11 months of age. These results indicate that the Eucalipto variety can be harvested in any of the evaluated seasons without losses to its quality. In contrast, for the Saracura, BRS Aipim Brasil and BRS Dourada varieties, it is recommended to harvest the roots at 12 or 15 months of age.

\section{Table 2}

\section{Physical and physico-chemical characteristics of the cassava varieties}

\begin{tabular}{|c|c|c|c|c|c|c|c|}
\hline Variable & Root age & Eucalipto & Saracura & $\begin{array}{l}\text { BRS Aipim } \\
\text { Brasil }\end{array}$ & $\begin{array}{c}\text { BRS } \\
\text { Dourada }\end{array}$ & Mean & $\begin{array}{l}\text { CV1 } \\
\text { (\%) }\end{array}$ \\
\hline \multirow{5}{*}{$\begin{array}{l}\text { Dietary fiber } \\
\text { (\%) }\end{array}$} & 9 & 2.34 & 2.21 & 2.11 & 2.43 & $2.27^{B}$ & 12.72 \\
\hline & 12 & 2.94 & 2.62 & 2.26 & 2.71 & $2.63^{A}$ & 14.45 \\
\hline & 15 & 2.38 & 2.15 & 2.12 & 2.59 & $2.31^{B}$ & 11.95 \\
\hline & Mean & $2.47^{\mathrm{ab}}$ & $2.32^{\mathrm{ab}}$ & $2.16^{b}$ & $2.65^{a}$ & & \\
\hline & CV2 (\%) & 13.49 & 16.34 & 4.00 & 13.44 & & \\
\hline \multirow{5}{*}{$\begin{array}{l}\text { Lipids }^{(1)} \\
\text { (\%) }\end{array}$} & 9 & 0.29 & 0.28 & 0.27 & 0.31 & $0.29^{\mathrm{B}}$ & 8.68 \\
\hline & 12 & 0.27 & 0.27 & 0.27 & 0.30 & $0.28^{\mathrm{B}}$ & 11.40 \\
\hline & 15 & 0.28 & 0.33 & 0.34 & 0.39 & $0.34^{A}$ & 14.38 \\
\hline & Mean & $0.28^{b}$ & $0.29^{a b}$ & $0.29^{\mathrm{ab}}$ & $0.33^{a}$ & & \\
\hline & CV2 (\%) & 6.01 & 11.60 & 14.22 & 17.98 & & \\
\hline \multirow{5}{*}{$\begin{array}{l}\text { Cyanogenic } \\
\text { compounds } \\
\left(\mu \mathrm{HCN} \mathrm{g}^{-1}\right)\end{array}$} & 9 & 8.34 & 9.78 & 10.67 & 10.08 & $9.72^{\mathrm{A}}$ & 22.54 \\
\hline & 12 & 6.36 & 7.69 & 6.99 & 11.72 & $8.19^{A}$ & 33.46 \\
\hline & 15 & 1.95 & 2.75 & 2.00 & 4.78 & $2.87^{\mathrm{B}}$ & 82.92 \\
\hline & Mean & $5.55^{b}$ & $6.74^{\mathrm{ab}}$ & $6.55^{\mathrm{ab}}$ & $8.86^{a}$ & & \\
\hline & CV2 (\%) & 65.02 & 49.78 & 62.31 & 45.14 & & \\
\hline \multirow{5}{*}{$\operatorname{Dry~matter}^{(2)}(\%)$} & 9 & $36.60^{\mathrm{aB}}$ & $33.58^{\mathrm{aB}}$ & $27.80^{\mathrm{bB}}$ & $29.86^{\mathrm{bA}}$ & 31.96 & 11.38 \\
\hline & 12 & $35.03^{\mathrm{aB}}$ & $35.13^{\mathrm{aB}}$ & $28.33^{\mathrm{bB}}$ & $26.68^{\mathrm{bB}}$ & 31.29 & 13.45 \\
\hline & 15 & $42.32^{\mathrm{aA}}$ & $42.37^{\mathrm{aA}}$ & $36.87^{\mathrm{bA}}$ & $32.78^{\mathrm{cA}}$ & 38.58 & 11.99 \\
\hline & Mean & 37.98 & 37.03 & 31.00 & 29.77 & & \\
\hline & CV2 (\%) & 9.16 & 11.08 & 15.72 & 10.42 & & \\
\hline
\end{tabular}


contuation...

\begin{tabular}{|c|c|c|c|c|c|c|c|}
\hline \multirow{5}{*}{$\operatorname{Starch}^{(2)(\%)}$} & 9 & $33.17^{\mathrm{aA}}$ & $31.21^{\mathrm{aB}}$ & $23.47^{\mathrm{bB}}$ & $24.84^{\mathrm{bA}}$ & 28.17 & 15.40 \\
\hline & 12 & $27.54^{\mathrm{aB}}$ & $26.95^{\mathrm{ac}}$ & $22.96^{\mathrm{bB}}$ & $20.72^{\mathrm{bB}}$ & 24.55 & 12.94 \\
\hline & 15 & $35.03^{\mathrm{bA}}$ & $38.97^{\mathrm{aA}}$ & $33.15^{\mathrm{bA}}$ & $27.63^{\mathrm{cA}}$ & 33.70 & 13.99 \\
\hline & Mean & 31.91 & 32.38 & 26.53 & 24.40 & & \\
\hline & CV2 (\%) & 11.27 & 16.44 & 20.55 & 13.05 & & \\
\hline \multirow{5}{*}{$\begin{array}{c}\text { Total } \\
\text { sugars }^{(2)(\%)}\end{array}$} & 9 & $0.98^{\mathrm{cA}}$ & $1.79^{\mathrm{bA}}$ & $1.15^{\mathrm{cA}}$ & $2.32^{\mathrm{aA}}$ & 1.56 & 38.03 \\
\hline & 12 & $1.16^{\mathrm{bcA}}$ & $1.54^{\mathrm{aA}}$ & $0.89^{\mathrm{cA}}$ & $1.38^{\mathrm{abB}}$ & 1.24 & 21.24 \\
\hline & 15 & $0.97^{\mathrm{aA}}$ & $1.09^{\mathrm{aB}}$ & $0.96^{\mathrm{aA}}$ & $1.06^{\mathrm{aC}}$ & 1.02 & 9.40 \\
\hline & Mean & 1.04 & 1.47 & 1.00 & 1.59 & & \\
\hline & CV2 (\%) & 11.38 & 24.10 & 15.68 & 37.12 & & \\
\hline \multirow{5}{*}{ Proteins $^{(2)}(\%)$} & 9 & $1.61^{\mathrm{aA}}$ & $1.39^{\mathrm{bA}}$ & $1.22 b^{c A}$ & $1.02^{\mathrm{cA}}$ & 1.31 & 19.32 \\
\hline & 12 & $1.22^{\mathrm{aB}}$ & $1.06^{\mathrm{aB}}$ & $1.14 a^{A B}$ & $0.39^{b c}$ & 0.95 & 36.94 \\
\hline & 15 & $0.81^{a b c}$ & $0.71^{\mathrm{bC}}$ & $0.99^{\mathrm{aB}}$ & $0.63^{\mathrm{bB}}$ & 0.78 & 19.04 \\
\hline & Mean & 1.21 & 1.05 & 1.12 & 0.68 & & \\
\hline & CV2 (\%) & 29.27 & 28.77 & 13.27 & 42.01 & & \\
\hline \multirow{5}{*}{$\mathrm{Ash}^{(2)(\%)}$} & 9 & $1.12^{\mathrm{aA}}$ & $1.07^{\mathrm{aAB}}$ & $0.97^{\mathrm{aA}}$ & $1.05 a^{\mathrm{AB}}$ & 1.05 & 12.53 \\
\hline & 12 & $1.11^{\mathrm{aA}}$ & $0.96^{\mathrm{aB}}$ & $0.99^{\mathrm{aA}}$ & $1.02^{\mathrm{aB}}$ & 1.02 & 7.34 \\
\hline & 15 & $0.99^{\mathrm{bA}}$ & $1.16^{\mathrm{aA}}$ & $1.11^{\mathrm{abA}}$ & $1.19^{\mathrm{aA}}$ & 1.11 & 8.75 \\
\hline & Mean & 1.07 & 1.06 & 1.03 & 1.08 & & \\
\hline & CV2 (\%) & 10.28 & 13.82 & 7.91 & 9.03 & & \\
\hline
\end{tabular}

(1) Non-significant interaction between the root variety and age factors. ${ }^{(2)}$ Significant interaction between the root variety and age factors. CV1 = coefficient of variation between varieties; CV2 = coefficient of variation between harvest ages. Means followed by common lowercase letters in the row and uppercase letters in the column do not differ at the $5 \%$ significance level by Tukey's test. 


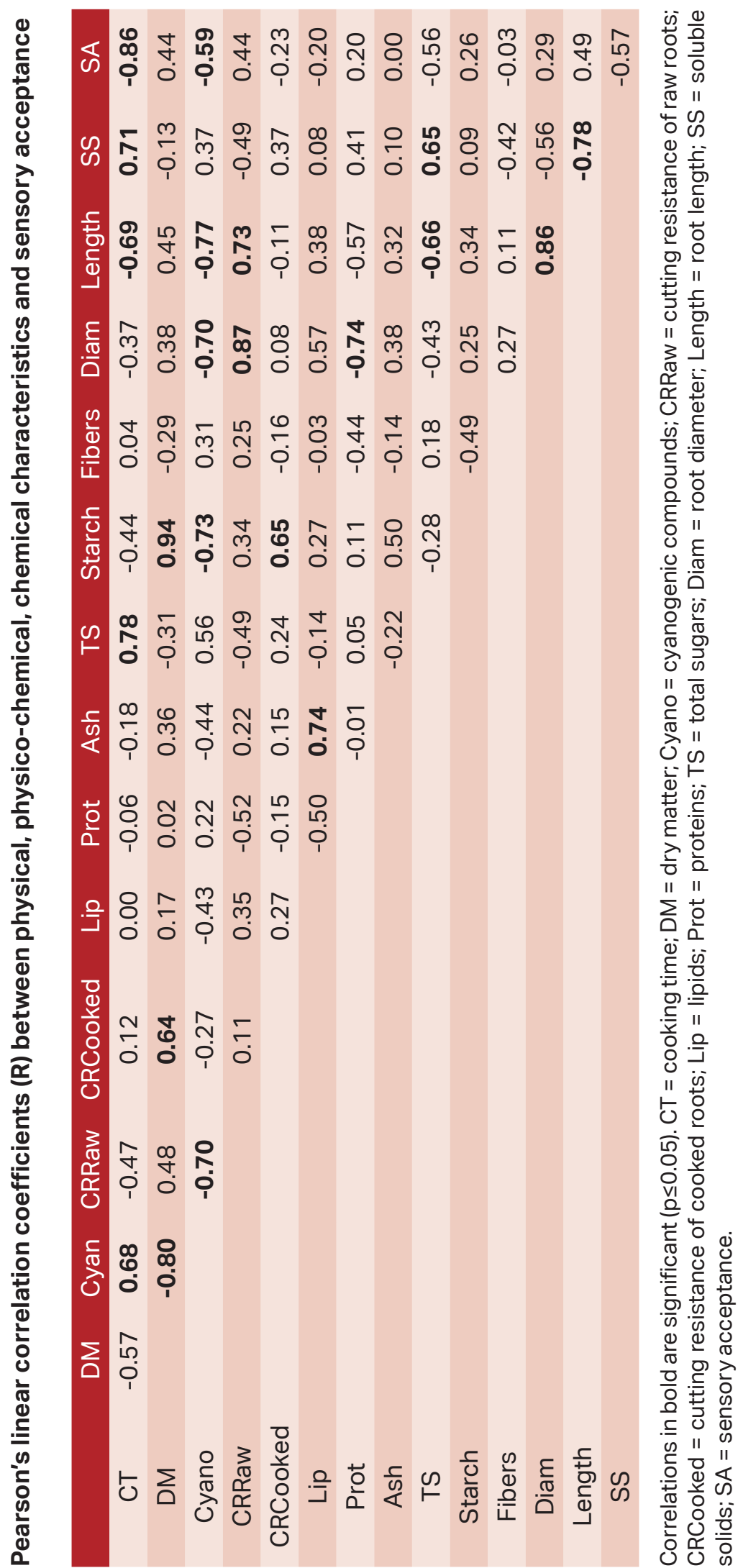


Cooking time showed a significant positive correlation $(p \leq 0.05)$ with soluble solids, cyanogenic compounds and total sugars (Table 3); therefore, the roots with the highest levels of these compounds had the longest cooking times. Contrary to these findings, Favaro, Beleia, Fonseca and Waldron (2008) observed no relationship between the chemical composition of cassava roots and cooking time.

The soluble solids contents were higher in the roots harvested at nine months. The Saracura and BRS Dourada varieties stood out with highest values for this variable: 7.70 and $8.11^{\circ}$ Brix, respectively (Table 1 ). Soluble solids decreased with root age, and, at 15 months, the four varieties did not differ from each other, averaging $5.23^{\circ}$ Brix.

The highest percentages of dietary fiber (Table 2) were observed in the roots harvested at 12 months (2.63\%). When the varieties were compared, BRS Dourada differed from BRS Aipim Brasil, which had the lowest content (2.16\%). Lower fiber values, between $0.80 \%$ and $1.02 \%$, were obtained by Sanoussi et al. (2015), who evaluated different varieties of cassava; and between $0.86 \%$ and $1.37 \%$, were described by Oliveira and Moraes (2009), who evaluated variety IAC 576-70 harvested at different ages. According to Carvalho, Cunha and Faria (2017), the fiber content is an important trait from the nutritional point of view, but for boiled cassava, roots with high levels may be less accepted by consumers, as they interfere with the softness of the product. Nevertheless, in this study, there was no correlation between fiber content and cutting resistance of the roots.

Varieties BRS Dourada and Eucalipto differed from each other in terms of lipid content (Table 2), and the varieties harvested at 15 months had the highest levels (0.34\%).
These findings corroborate the results of Beleia, Yamashita, Moraes, Silveira and Miranda (2004), who described that the lipid content of the roots increased with planting time. Similar values, between $0.4 \%$ and $0.5 \%$, were reported by Favaro et al. (2008), who evaluated three cassava varieties.

The cyanogenic compounds concentration was low in all evaluated varieties, ranging between 1.95 and $11.72 \mu \mathrm{g} \mathrm{HCN} \mathrm{g}^{-1}$ (Table 2). The BRS Dourada variety had the highest content, $8.86 \mu \mathrm{g}$ of $\mathrm{HCN} \mathrm{g}^{-1}$, and differed significantly from Eucalipto, which showed, on average, $5.55 \mu \mathrm{g} \mathrm{HCN} \mathrm{g}{ }^{-1}$. These compounds decreased significantly in all varieties with root age, averaging $2.87 \mu \mathrm{g} \mathrm{HCN} \mathrm{g}^{-1}$ at 15 months. The cyanogenic compound values are below the maximum limit of $50 \mu \mathrm{g} \mathrm{HCN} \mathrm{g}{ }^{-1}$ defined by the Food and Agriculture Organization of the United Nations/World Health Organization [FAO/WHO] (2012) for sweet cassava. In the study conducted by Fuhrmann et al. (2020), much higher values were reported for different cassava clones, ranging between 25 and $85 \mu \mathrm{g}$ $\mathrm{HCN} \mathrm{g}^{-1}$.

At 15 months, the four varieties had the highest dry matter and starch contents (Table 2). When the four varieties were compared, BRS Aipim Brasil and BRS Dourada showed the lowest levels of dry matter and starch, at all harvest ages. The dry matter levels observed for the roots of the varieties harvested at 15 months of age are in line with those reported by Kouadio et al. (2011), between $37.9 \%$ and 45.1\%; and by Sanoussi et al. (2015), between $42.34 \%$ and $44.67 \%$. According to Sanoussi et al. (2015), roots with high dry matter contents can contribute to increased yield in the field and are interesting for developing products derived from cassava, such as gari and tapioca. However, for the consumption of the 
boiled cassava roots, this parameter is not considered the most relevant. Rather, cooking time and the sensory characteristics are the factors that will determine the acceptance of the varieties by the consumers.

The starch content ranged from $20.72 \%$, for the BRS Dourada variety harvested at 12 months, to $38.97 \%$, for Saracura harvested at 15 months. This variable also showed a high significant correlation $(R=0.94)$ with dry matter content (Table 3). However, there were no significant correlations between cooking time and these two variables. Thus, it cannot be said that these variables directly influenced the cooking time of the roots, similar to the results obtained by Kouadio et al. (2011).

A variation between $0.89 \%$ and $2.32 \%$ was observed for the sugar content across the varieties. These values are close to the range of $1.76 \%$ to $2.57 \%$ found by Padonou et al. (2005) in boiled cassavas of different varieties. The roots of BRS Dourada and Saracura, harvested at nine months, showed the highest levels of total sugars, which were reduced with root age (Table 2). The roots of the Eucalipto and BRS Aipim Brasil varieties maintained similar sugar levels at all ages, and at 15 months, the four varieties did not differ from each other, averaging 1.02\% of total sugars. A positive correlation ( $R=0.78$ ) between total sugars and cooking time was observed in the varieties (Table 3).

The protein content of the roots varied from $0.39 \%$ to $1.61 \%$. Except for BRS Dourada, there was a decrease in the protein content of all varieties as they remained in the field. Beleia et al. (2004) did not observe any variation in the protein content according to root age for the cassava varieties IAPAR-19, Pioneira and Caratarina Amarela harvested at 12 and 25 months. However, Oliveira and Moraes (2009) reported variations in the protein content of variety IAC 576-70 according to root age, with values above $1 \%$ obtained from nine months of age. From a nutritional point of view, cassava varieties with higher protein content are desirable.

A small variation was observed for the ash content, which ranged between $0.96 \%$ (Saracura, harvested at 12 months) and 1.19\% (BRS Dourada at 15 months) and agreed with the 0.75 to $1.0 \%$ obtained by Oliveira and Moraes (2009) in the roots of IAC 576-70. When analyzed based on root age, the ash content did not change significantly for the Eucalipto or BRS Aipim Brasil varieties, whereas in BRS Dourada and Saracura a small increase was seen at 15 months. The ash content is directly related to minerals, a positive nutritional characteristic.

The first two PCA components accounted for $64.26 \%$ of the total variance (Figure 1A) and allowed the distribution of the cassava varieties harvested in the three seasons.

As can be seen in Figure 1B, PC1 was positively correlated with the characteristics of cyanogenic compounds, cooking time and total sugars and negatively correlated with length, diameter, cutting resistance of raw roots, dry matter and starch. This component discriminated roots according to age, separating the varieties harvested at nine months from those harvested at 15 months. The roots of the BRS Aipim Brasil, BRS Dourada and Saracura varieties, harvested at nine months, showed higher levels of cyanogenic compounds and sugars and longer cooking times. The cassava roots harvested at 15 months are distinguished by greater length, diameter, cutting resistance of raw roots, dry matter and starch, and by lower levels of cyanogenic compounds and sugars and shorter cooking times. 

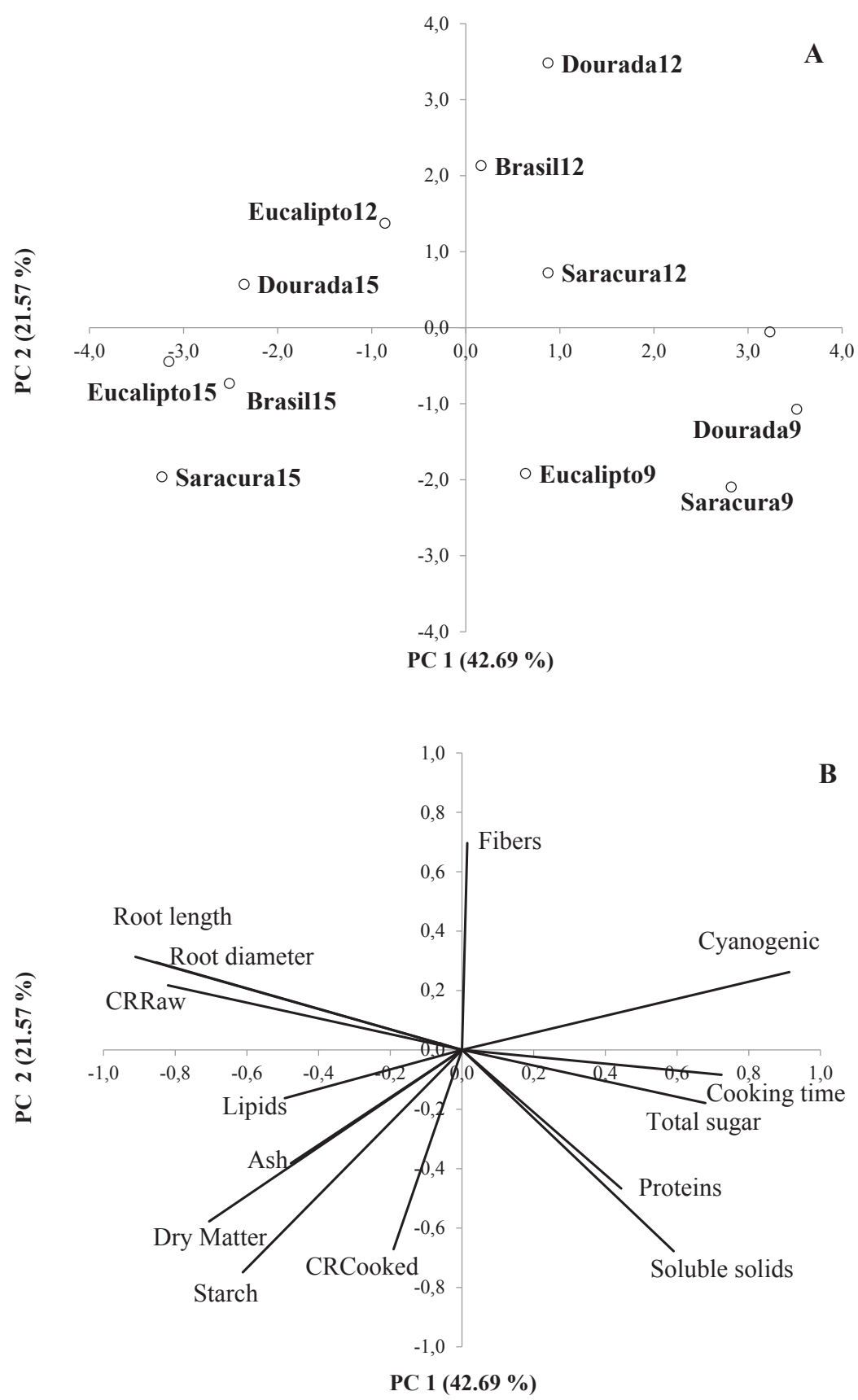

Figure 1. Principal component analysis of physical, physico-chemical and chemical characteristics of cassava varieties harvested at three ages. CRRaw: cutting resistance (raw roots); CRCooked: cutting resistance (cooked roots). A: Sample scatter. B: Loadings (correlations) between the characteristics and the two principal components. 
PC2 was positively correlated with the dietary fiber, but negatively correlated with starch, soluble solids and cutting resistance of cooked roots, differentiating the cassava varieties harvested at 12 months from the others. At this harvest time, the cassava roots had higher dietary fiber contents, lower levels of total starch and soluble solids and less resistance to cutting after cooking.
There was a significant interaction $(p<0.05)$ between the root age and variety factors for sensory acceptance (Table 4). Differences were detected between the four varieties, and, at nine months, the Saracura variety had the lowest acceptance score (5.0), differing from Eucalipto, which had an average score of 6.3. At 12 months of age, there was a significant increase in the acceptance of the Saracura and BRS Aipim Brasil varieties, which did not differ from the Eucalipto variety and averaged 6.4.

Table 4

Acceptance ${ }^{1}$ of the four varieties of cassava harvested at three different ages

\begin{tabular}{ccccccc|}
\hline Root age & Eucalipto & Saracura & BRS Aipim Brasil & BRS Dourada & Mean & CV1 \\
\hline 9 & $6.3^{\mathrm{aA}}$ & $5.0^{\mathrm{bB}}$ & $5.3^{\mathrm{abB}}$ & $5.4^{\mathrm{abA}}$ & 5.5 & 9.4 \\
12 & $6.3^{\mathrm{aA}}$ & $6.3^{\mathrm{aA}}$ & $6.5^{\mathrm{aA}}$ & $5.3^{\mathrm{bA}}$ & 6.1 & 9.4 \\
15 & $6.4^{\mathrm{aA}}$ & $5.8^{\mathrm{aAB}}$ & $6.3^{\mathrm{aA}}$ & $5.6^{\mathrm{aA}}$ & 6.0 & 6.3 \\
Mean & 6.3 & 5.7 & 6.0 & 5.4 & & \\
CV2 & 1.2 & 11.1 & 10.3 & 3.4 & \\
\hline
\end{tabular}

${ }^{1}$ Mean acceptance score in a nine-point hedonic scale. CV1 = coefficient of variation between varieties; CV2 = coefficient of variation between harvest ages. Means followed by common lowercase letters in the row and uppercase letters in the column do not differ at the $5 \%$ significance level by Tukey's test.

When the three root ages were evaluated, the BRS Dourada and Eucalipto varieties maintained similar mean scores at all times. Therefore, these varieties can be harvested at any time without significant changes in their acceptance. Saracura and BRS Aipim Brasil showed different results, obtaining the highest acceptance scores when harvested at 12 or 15 months. According to Beleia et al. (2006), there is no way to define an exact time to harvest cassava, as this depends on the convenience of the producer and the market. On this basis, varieties that can be harvested later, without quality losses, may be more interesting for the producer and consumer markets.

Sensory acceptance was significantly correlated with cooking time $(R=-0.86)$ (Table 3), indicating that the roots with the shortest cooking time were the most wellaccepted. The other characteristics did not exhibit a significant correlation with sensory acceptance.

Significant differences were observed for 12 out of the 16 terms used to describe the samples by CATA, at least at one harvest age (Table 5). This result suggests that the 
attributes assigned using CATA were adequate to discriminate the evaluated cassava varieties. Only the terms "green corn aroma", "cassava taste", "no taste/watery" and "sticky" were not considered relevant to differentiate these varieties.

The terms associated with color ("cream", "yellow" and "white") and texture ("soft", "hard", "creamy" and "floury") were relevant to discriminate the varieties at the three harvest ages. The term "cassava aroma" was significant to differentiate the roots harvested at nine months, whereas the term "fibrous", differentiated the roots when harvested at 12 months. The terms "sweet" and "slightly bitter" were only significant to differentiate the varieties harvested at 15 months, as was the "shiny aspect". These results indicate that sensory characteristics change with root age and that this variation occurs differently for each variety. The same was observed for some physico-chemical and chemical characteristics, thus reinforcing the importance of defining the best age for harvesting each cassava variety.
Figure 2A shows that the first two dimensions explained $95.79 \%$ of the total inertia, thus being sufficient to discriminate the four varieties harvested at nine months of age. The terms related to the color of the roots differentiate the varieties in relation to the first dimension, with the color "yellow" associated with the roots of varieties Eucalipto and BRS Dourada, and the colors "cream" and "white" with varieties BRS Aipim Brasil and Saracura, respectively, positioned on the opposite side. Eucalipto was also associated with the terms "sticky", "soft" and "creamy", and this variety was the most accepted at nine months (Table 3 ) and had the shortest cooking time (Table 1). The terms "hard" and "green corn aroma" were associated with the BRS Dourada and Saracura varieties, whose cooking time was longer than 40 min (Table 1). Saracura also received the terms "no taste/watery" and "floury" and was the variety that had the lowest score of acceptance at nine months (Table 3). 


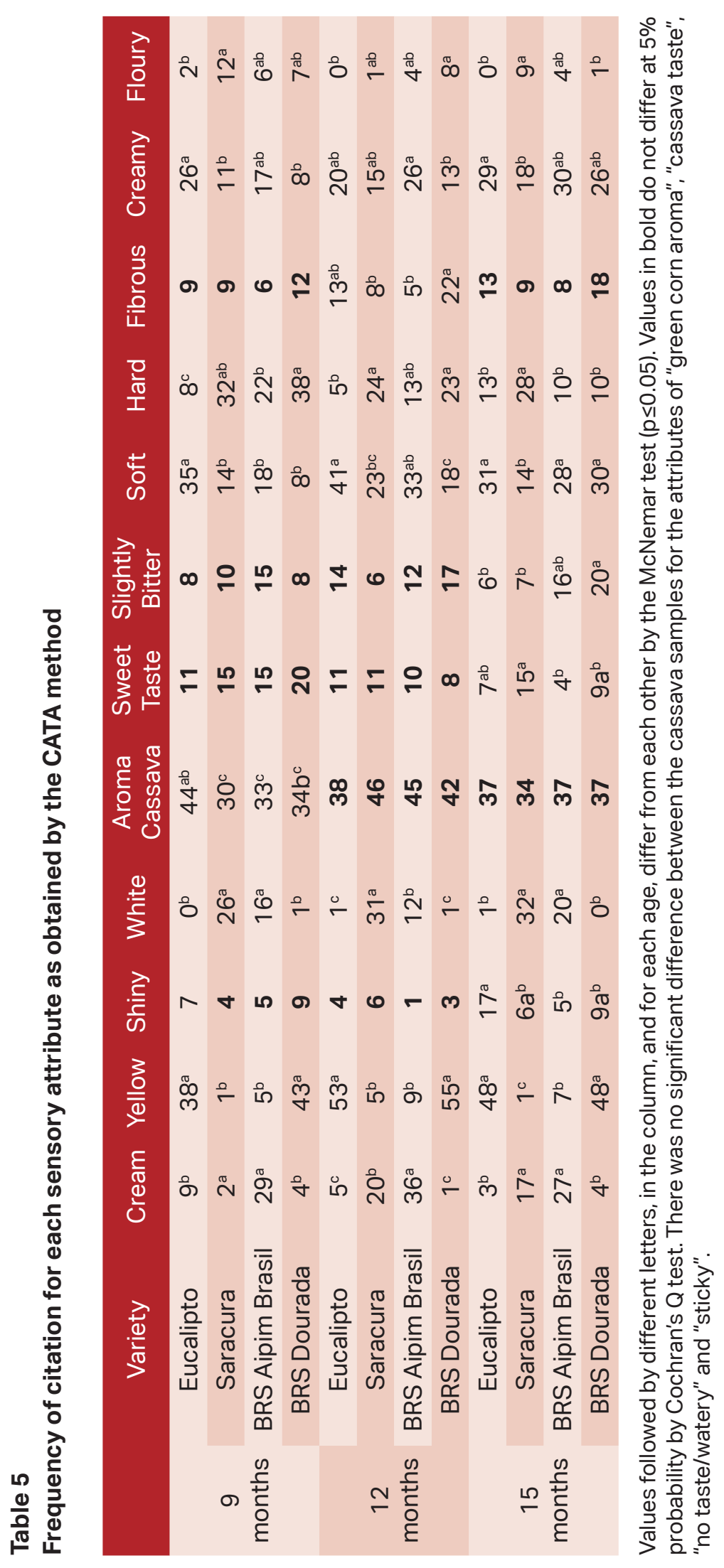


At 12 months of age, the first two dimensions explained $87.73 \%$ of the total inertia and there was a change in the characteristics of the harvested roots (Figure 2B). The BRS Dourada and Eucalipto varieties remained located on the right side of the graph, and "yellow color" was again associated with these two varieties. The roots of the Eucalipto variety were associated mainly with the terms "soft", "sticky" and "creamy". In contrast, the BRS Dourada variety was associated with the terms "hard texture", "floury" and "fibrous". This variety had the highest dietary fiber content (Table 2). The terms "cassava taste", "sweet taste" and "cassava aroma" characterized the Saracura and BRS Aipim Brasil varieties. However, Saracura was also associated with the terms "hard texture", "shiny aspect" and "white color", whereas BRS Aipim Brasil was related to the terms "cream color", "creamy", "sticky" and "soft".

It is important to stress that although there was no difference regarding the physical measurements of texture between the varieties (Table 1), the consumers perceived a difference in the sensory texture of the roots in evaluating the four varieties. This behavior shows the importance of conducting studies with consumers when evaluating the quality of boiled cassava.

When we compare this result with those of the acceptance test (Table 4), the Saracura and BRS Aipim Brasil, which had an increase in average acceptance at 12 months, were found to be associated with different terms as compared to nine months. For Saracura, probably the absence of the term "floury" and the presence of the terms "cassava taste", "sweet taste" and "cassava aroma" may have positively influenced the increase in the acceptance of this variety. The same occurred for BRS Aipim Brasil, which, in addition to these three terms, also had the "creamy", "sticky" and "soft" characteristics when harvested at 12 months. On the other hand, BRS Dourada received the lowest acceptance score at 12 months, which indicates that the terms "floury" and "fibrous" may be related to the lesser acceptance of the roots. 

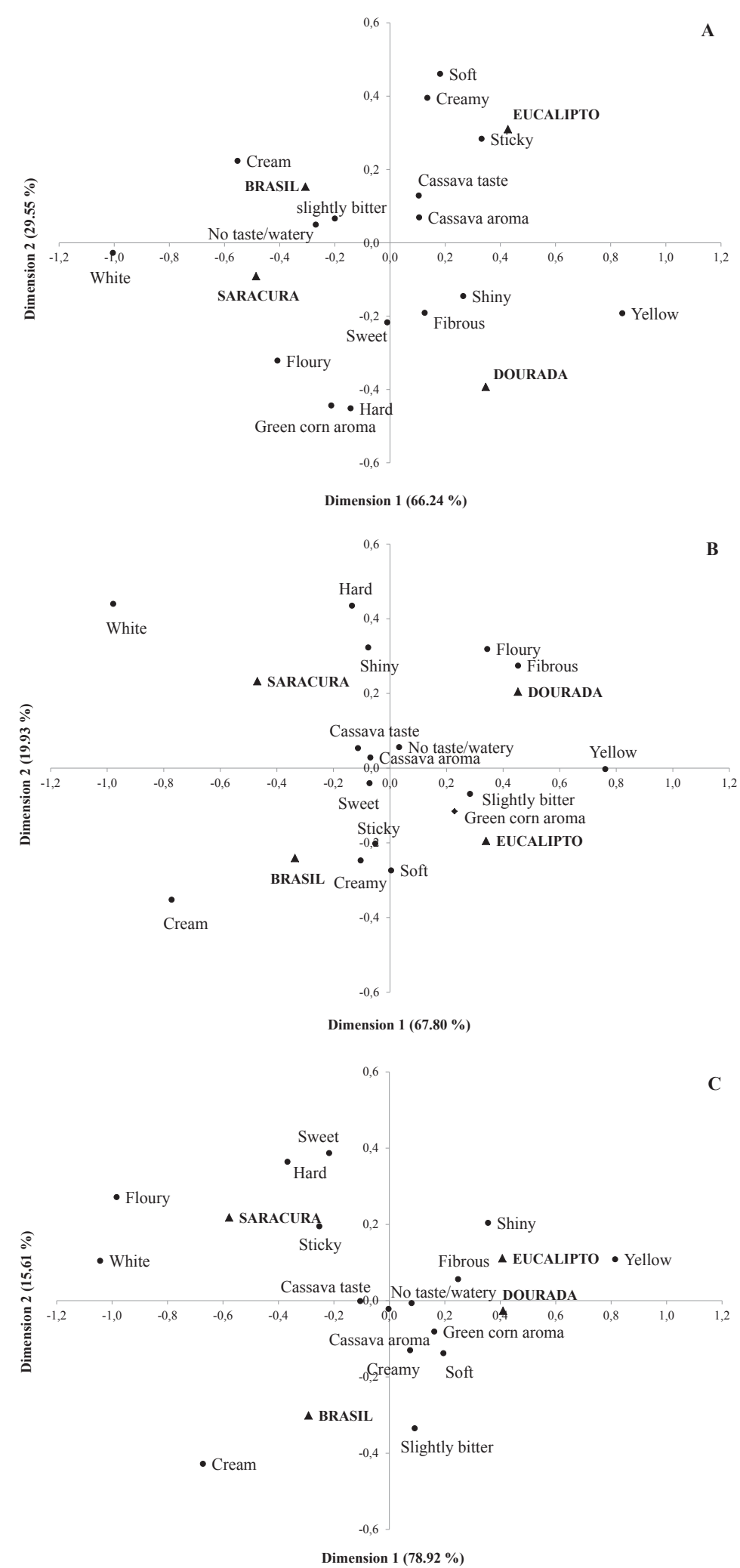

Figure 2. Correspondence analysis of the CATA questionnaire data. Varieties harvested at nine months (A), 12 months (B) and 15 months (C). 
At 15 months of age, the first two dimensions explained $94.53 \%$ of inertia (Figure 2C) and, just as at nine and 12 months, flesh color was the trait responsible for the differentiation between the BRS Dourada and Eucalipto varieties (both yellow color) and the Saracura and BRS Aipim Brasil varieties, which are characterized by the white and cream flesh colors, respectively. The roots of the BRS Dourada and Eucalipto varieties were considered to have similar characteristics by the evaluators, who ascribed the terms "soft", "green corn aroma", "shiny aspect", "fibrous", "creamy", "slightly bitter" and "no taste/watery". These two varieties did not differ significantly in sensory acceptance at 15 months of age (Table 4).

The term "hard" was associated with the Saracura variety at the three harvest ages, and, at 15 months, this variety once again was ascribed the term "floury". The BRS Aipim Brasil variety was characterized by the terms "cassava aroma" and "cassava taste" and maintained the same acceptance score at 15 months of age.

The results of correspondence analysis with the CATA data (Figure 2) and the result of the acceptance test (Table 4) reveal that the terms related to texture and taste were directly associated with the acceptance of the varieties. Characteristics such as "creamy", "soft" and "sticky" can be associated with greater acceptance of cassava roots. Characteristics such as "floury", "slightly bitter", "no taste", "hard" and "fibrous" seem to be associated with lower acceptance of the roots and, as such, undesirable for the evaluated varieties. In the studies led by Franck et al. (2011) and Padonou et al. (2005), with trained assessors, texture and taste were considered the most important attributes to describe the quality of cooked roots; however, sensory acceptance and CATA tests were not performed, so a direct comparison with the results presented in this study was not possible.

\section{Conclusion}

Harvest age has a significant effect on the culinary quality of boiled cassava, regardless of the evaluated variety.

Commercial variety Eucalipto was wellaccepted by the consumers irrespective of root age. Therefore, it can be harvested at any of the evaluated ages.

The Saracura variety should preferably be harvested at 12 months since the roots were more accepted at that age. For the BRS Aipim Brasil and BRS Dourada varieties, harvest is recommended at 12 or 15 months so that better quality roots are obtained.

\section{Acknowledgments}

The authors thank FAPESB for the Undergraduate Research fellowship grant and Embrapa for the financial resource.

\section{References}

Agritempo (2020). Sistema de Monitoramento Agrometeorológico do Ministério da Agricultura Pecuária e Abastecimento. Recuperado de http://www.agritempo.gov. br/agritempo/index.jsp

Aguiar, L. A., Rodrigues, D. B., Queiroz, V. A. V., Melo, L., \& Pineli, L. L. O. (2020). Comparison of two rapid descriptive sensory techniques for profiling and 
screening of drivers of linking of sorghum breads. Food Research International, 131, 1-12. doi: 10.1016/j.foodres.2020.108999

Araújo, J. C., \& Almeida, C. O. (2013). Inventário de variedades de mandioca lançadas pela EMBRAPA Mandioca e Fruticultura no período de 1996 a 2009. (Circular Técnica, 107). Cruz das Almas: EMBRAPA Mandioca e Fruticultura.

Ares, G., Barreiro, C., Deliza, R., Giménez, A., \& Gámbaro, A. (2010). Application of a checkall-that-apply question to the development of chocolate milk desserts. Journal of Sensory Studies, 25(Supl. 1), 67-86. doi: 10.1111/j.1745-459x.2010.00290.x

Beldarrain, L. R., Etaio, I., Morán, L., Sentandreu, M.A., Barron, L. J.R., \&Aldai, N. (2020). Effect of ageing time on consumer preference and sensory description of foal meat. Food Research International, 129, 108871. doi: 10.1016/j.foodres.2019.108871

Beleia, A., Butarelo, S. S., \& Silva, R. S. F. (2006). Modeling of starch gelatinization during cooking of cassava (Manihot esculenta Crantz). LWT - Food Science and Technology, 39(4), 399-404. doi: 10. 1016/j.Iwt. 2005.02.021

Beleia, A., Yamashita, F., Moraes, S. R., Silveira, C. A., \& Miranda, L. A. (2004). Textural changes during cooking of cassava (Manihot esculenta Crantz) roots. Journal of the Science of Food and Agriculture, 84, 1975-1978. doi: 10.1002/jsfa.1917

Boukid, F., Gentilucci, V., Vittadini, E., Montis, A. de, Rosta, R., Bose, S., Carini, E. (2020). Rediscovering bread quality of "old" Italian wheat (Triticum aestivum L. ssp. Aestivum) through an integrated approach: Physicochemical evaluation and consumer's perception. LWT- Food Science and Tecnology, 122, 109043. doi: 10.1016/j.Iwt.2020.109043

Carvalho, A. V., Cunha, E. F. M., \& Faria, J. T., Neto. (2017). Caracterização físico-química de genótipos de macaxeira cultivados no estado do Pará. Belém PA: Embrapa Amazônia Oriental. (Boletim de Pesquisa e Desenvolvimento, 120). Recuperado de https://www.embrapa.br/amazoniaoriental/ publicacoes

Carvalho, H. W. L., Fukuda, W. M. G., Ribeiro, F. E., Oliveira, V. D., Ribeiro, S. S., \& Rodrigues, K. F. (2007). Comportamento de variedades de aipim no estado de Sergipe. (Boletim de Pesquisa e Desenvolvimento, 20). Aracaju SE: EMBRAPA Tabuleiros Costeiros. Recuperado de https://ainfo. cnptia.embrapa.br/digital/bitstream/ CPATC/19760/1/bp-20.pdf

Cooke, R. D. (1979). Enzymatic assay for determining the cyanide content of cassava and cassava products. Cali: Centro Internacional de Agricultura Tropical 05EC-6.

Essers, A. J. (1994). Further improving the enzymic assay for cyanogens in cassava products. Acta Horticulturae, 375, 97-104. doi: 10.17660/ActaHortic.1994.375.7

Favaro, S. P., Beleia, A., Fonseca, N. S., Jr., \& Waldron, K. W. (2008). The roles of cell wall polymers and intracelular components in the thermal softening of cassava roots. Food Chemistry, 108, 220-227. doi: 10.1016/j.foodchem.2007.10.070

Feniman, C. M. (2004). Caracterização de raízes de mandioca (Manihot esculenta Crantz) do cultivar IAC 576-70 quanto à cocção, composição química e propriedades 
do amido em duas épocas de colheita. Dissertação de mestrado, Escola Superior de Agricultura "Luiz de Queiroz", Universidade de São Paulo, Piracicaba, SP, Brasil.

Food and Agriculture Organization of the United Nations (2020). Crops. Retrieved from: http://www.fao. org/faostat/en/\#data/QC

Food and Agriculture Organization of the United Nations/World Health Organization (2012). Safety evaluation of certain food additives and contaminants. Geneva: WHO Food Additives Series.

Franck, H., Christian, M., Noel, A., Brigitte, P., Joseph, H. D., Cornet, D., \& Mathurin, N. C. (2011). Effects of cultivar and harvesting conditions (age, season) on the texture and taste of boiled cassava roots. Food Chemistry, 126, 127-133. doi: 10.1016/j. foodchem.2010.10.088

Fuhrmann, E., Vieira, E. A., Fialho, J. F., Faleiro, F. G., Malaquias, J. V., \& Carvalho, L. J. C. B. (2020). Agronomic and biochemical evaluation of cassava clones with roots that have pink pulp. Ciência Rural, 50(1), e20180910. doi: 10.1590/0103$8478 \mathrm{cr} 20180910$

Holm, J. H., \& Bjorck, N. G. (1986). A rapid method for the analysis of starch. Starch, 38(7), 224-226. doi: 10.1002/star.19860380704

Instituto Brasileiro de Geografia e Estatística (2019). Produção agrícola municipal, 2018.

Jaeger, S. R., Beresfor, M. K., Lo, K. R., Hunter, D. C., Chheang, S. L., \& Ares, G. (2020). What does it mean to check-all-that-apply? Four case studies with beverages. Food Quality and Preference, 80, 103794. doi: 10.1016/j.foodqual.2019.103794
Kouadio, K. O., Nindjin, C., Bonfoh, B., N'Dri, D., \& Amani, G. N. (2011). Water absorption as an evaluation method of cooking quality for yam (Dioscorea alata) and cassava (Manihot esculenta crantz). Procedia Food Science, 1, 153-159. doi: 10.1016/j. profoo.2011.09.024

Lado, J., Vicente, E., Manzzioni, A., \& Ares, G. (2010). Application of a check-allthat-apply question for the evaluation of strawberry cultivars from a breeding program. Journal of the Science of Food and Agriculture, 90, 2268-2275. doi: 10.1002/jsfa.4081

Ministério da Agricultura Pecuária e Abastecimento. Métodos analíticos oficiais físico-químicos para controle de leite e produtos lácteos. Instrução Normativa $n^{\circ}$ 68, de 12/12/2006. Recuperado de http:// extranet.agricultura. gov.br/sislegis-consulta/servlet/ VisualizarAnexo?id=1802

Nelson, N. (1944). A photometric adaptation of the Somogyi method for the determination of glucose. The Journal of Biological Chemistry, 153(2), 375-380.

Oliveira, E. W., Esmerino, E. A., Carr, B. T., Pinto, L. P. F., Silva, H. L. A., Pimentel, T. C.,... Freitas, M. Q. (2017). Reformulating Minas Frescal cheese using consumer's perceptions: Insights from intensity scales and checkall-that-apply questionnaires. Journal of Dairy Science, 100(8), 6111-6124. doi: 10. 3168/jds. 2016-12335

Oliveira, M. A., \& Moraes, P. S. B. (2009). Características físico-químicas, cozimento e produtividade de mandioca cultivar IAC 576-70 em diferentes épocas de colheita. Ciência e Agrotecnologia, 33(3), 837-843. doi: 10.1590/S1413-70542009000300024 
Oliveira, S. P., Viana, A. E. S., Matsumoto, A. N., Cardoso, N. S., Jr., Sediyama, T., \& José, A. R. S. (2010). Efeito da poda e de épocas de colheita sobre as características agronômicas da mandioca. Acta Scientiarum. Agronomy, 32(1), 99-108. doi: 10.4025/actasciagron.v32i1.922

Padonou, W., Mestres, C., \& Nago, M. C. (2005). The quality of boiled cassava roots: instrumental characterization and relationship with physicochemical properties and sensory properties. Food Chemistry, 89, 261-270. doi: 10.1016/j. foodchem.2004.02.033

Pedri, E. C.M., Rossi, A. A. B., Cardoso, E.S., Tiago, A. V., Hoogerheide, E. S. S., \& Yamashita, O. M. (2018). Características morfológicas e culinárias de etnovariedades de mandioca de mesa em diferentes épocas de colheita. Brazilian Journal of Food Technology, 21(e2018073), e2018073. doi: 10.1590/ 1981-6723.07318

R Core Team (2018). R: A language and environment for statistical computing. Vienna: $R$ Foundation for Statistical Computing. Retrieved from http://www.Rproject.org

Rodriguez-Amaya, D., \& Kimura, M. (2004). HarvestPlus handbook for carotenoid analysis. Cali: IFPRI: CIAT.
Sanoussi, A. F., Loko, L. Y., Ahissou, H., Adjahi, A. K., Orobiyi, A., Agré, A. P.,... Sanni, A. (2015). Diversity, physicochemical and technological characterization of elite cassava (Manihot esculenta Crantz) cultivars of Bantè, a district of Central Benin. The Scientific World Journal, (674201), 1-8. doi: 10.1155/2015/674201

Santos, H. G., Jacomine, P. K., Anjos, L. H. C., Oliveira, V. A., Lumbreras, J. F., Coelho, M. R., Cunha, T. J. F. (2018). Sistema brasileiro de classificação de solos. Brasília, DF: EMBRAPA.

Somogyi, M. (1945). A new reagent for the determination of sugar. The Journal of Biological Chemistry, 160(1), 61-68.

STATSOFT (2008). Statistics for Windows 7.0. Tulsa: STATSOFT.

Talma, S. V., Almeida, S. B., Lima, R. M. P., Vieira, H. D., \& Bervert, P. A. (2013). Tempo de cozimento e textura de raízes de mandioca, Brazilian Journal of Food Technology, 16 (2), 133-138, doi: 10.1590/ S1981-67232013005000016

Zenebon, O., Pascuet, N. S., Tiglea, P. (2008). Métodos físico-químicos para análise de alimentos. São Paulo: Instituto Adolfo Lutz. 